Article

\title{
Gut Bacterial Communities of Dendroctonus valens and D. mexicanus (Curculionidae: Scolytinae): A Metagenomic Analysis across Different Geographical Locations in Mexico
}

\author{
Juan Alfredo Hernández-García 1,2 (i), Roman Gonzalez-Escobedo 1,2 (i), \\ Carlos Iván Briones-Roblero ${ }^{2}$, Claudia Cano-Ramírez ${ }^{2}$, Flor N. Rivera-Orduña ${ }^{3}$ and \\ Gerardo Zúñiga ${ }^{2, *}$ \\ 1 Posgrado en Ciencias Quimicobiológicas, Escuela Nacional de Ciencias Biológicas, Instituto Politécnico \\ Nacional, Mexico City, CP 11340, Mexico; freddyhardcore@hotmail.com (J.A.H.-G.); \\ romanglze@hotmail.com (R.G.-E.) \\ 2 Laboratorio de Variación Biológica y Evolución, Departamento de Zoología, Escuela, Nacional de Ciencias \\ Biológicas, Instituto Politécnico Nacional, Prolongación de Carpio y Plan de Ayala s/n, Delegación Miguel \\ Hidalgo, Mexico City, CP 11340, Mexico; cabriones13@gmail.com (C.I.B.-R.); \\ clacanram@yahoo.com.mx (C.C.-R.) \\ 3 Laboratorio de Ecología Microbiana, Departamento de Microbiología, Escuela Nacional de Ciencias \\ Biológicas, Instituto Politécnico Nacional, Prolongación de Carpio y Plan de Ayala s/n, Delegación Miguel \\ Hidalgo, Mexico City, CP 11340, Mexico; flor_1413@hotmail.com \\ * Correspondence: capotezu@hotmail.com; Tel.: +52-555-729-6000 (ext. 62418)
}

Received: 7 August 2018; Accepted: 23 August 2018; Published: 30 August 2018

\begin{abstract}
Dendroctonus bark beetles are a worldwide significant pest of conifers. This genus comprises 20 species found in North and Central America, and Eurasia. Several studies have documented the microbiota associated with these bark beetles, but little is known regarding how the gut bacterial communities change across host range distribution. We use pyrosequencing to characterize the gut bacterial communities associated with six populations of Dendroctonus valens and D. mexicanus each across Mexico, determine the core bacteriome of both insects and infer the metabolic pathways of these communities with Phylogenetic Investigation of Communities by Reconstruction of Unobserved States (PICRUSt) to evaluate whether these routes are conserved across geographical locations. Our results show that the $\beta$-diversity with UniFrac unweighted varies among locations of both bark beetles mainly due to absence/presence of some rare taxa. No association is found between the pairwise phylogenetic distance of bacterial communities and geographic distance. A strict intraspecific core bacteriome is determined for each bark beetle species, but these cores are different in composition and abundance. However, both bark beetles share the interspecific core bacteriome recorded previously for the Dendroctonus genus consisting of Enterobacter, Pantoea, Providencia, Pseudomonas, Rahnella, and Serratia. The predictions of metabolic pathways are the same in the different localities, suggesting that they are conserved through the geographical locations.
\end{abstract}

Keywords: gut bacteriome; core bacteriome; geographical variation

\section{Introduction}

Dendroctonus Erichson (Curculionidae: Scolytinae) bark beetles are not only a natural inhabitant of coniferous forests but also a major pest during the periodic outbreaks in pine forests from North and Central America [1,2]. Many studies have revealed that these insects are associated with facultative 
microbes, and it has been demonstrated through in vitro tests, the amplification of specific gene, and sequencing technologies that some of the microbes provide benefits to bark beetles favoring their adaptation and reproductive success [3-6]. Bacteria can aid in the digestion of plant structural carbohydrates [7-9], nitrogen fixation and recycling [10-13], terpene detoxification [14-16], pheromone production [17], protection against antagonistic fungi [18,19], and mediation of carbohydrate consumption and growth of associated fungi [20].

Several studies using conventional techniques and massive parallel sequencing technologies have allowed the determination of the bacterial community structure associated with the inside (e.g., gut and mycangium) and the outside (e.g., mouthparts and cuticle) of the bark beetles body [7,12,21-28], galleries [29], and specific developmental stages of some species [30,31]. In addition, the presence of two core bacteriomes, one strict (composed by Enterobacter, Serratia, Rahnella, Pantoea, Raoultella, and Pseudomonas) and another relaxed (constituted of the strict core plus Acinetobacter, Propionibacterium, Providencia, Stenotrophomonas, Erwinia, Kluyvera, Paenibacillus, and Ralstonia) in the gut has been recently determined in different Dendroctonus species [28], which suggests that some of these taxa probably support basic metabolic processes that benefit these bark beetles.

Based on this evidence, and notwithstanding that the Dendroctonus bark beetles' gut presumably is a heterogeneous yet limiting habitat, it is reasonable to hypothesize that the strict core bacteriome of these insects should be stable across the distribution range of species, despite the variation in the richness and evenness of the bacterial community across the geographical space. Three pieces of evidence support this idea: (1) The low bacterial diversity observed in many studies performed on bark beetles [26,27,30], and other insects with a similar diet as pine weevils [32], and cerambycids [33] with respect to those found in other phytophagous insects [34-37]; (2) The dominance of some taxa of the core bacteriome and the presence/absence of rare taxa [28]; and (3) The higher diversity of endophytic bacteria found in the pine species phloem, a substrate on which bark beetles feed, with respect to the diversity found in their gut [38].

There were two aims in this study: (1) To analyze the gut bacterial community of two bark beetle species, Dendroctonus valens LeConte and D. mexicanus Hopkins, across six different geographic localities using 16S rRNA pyrosequencing. The first species has a wide distribution in North and Central America, where it is a parasite of stumps or trees of more than 40 pine species $[39,40]$, while the second species is found mainly in Mexico and it is an aggressive species that attacks and kills approximately 20 pine species in its distribution range [39]; (2) To infer the metabolic pathways of the entire bacterial community in each locality of these bark beetles with the Phylogenetic Investigation of Communities by Reconstruction of Unobserved States (PICRUSt) to evaluate whether these metabolic processes are conserved across the geographical space studied. Although we have some idea of the specific metabolic capacities of some bacterial species found in the bark beetles' gut, this inference is the first approximation to know the integral functional role of the entire community, as well as to explore whether the predicted metabolic pathways are maintained across the geographic space.

\section{Results}

\subsection{Taxonomic Analysis of Gut Bacterial Communities}

A total of 155,324 and 297,425 raw reads were obtained from six localities (Figure 1, Table S1) and replicates for Dendroctonus valens and D. mexicanus, respectively. After the quality control, 86,349 reads for D. valens and 101,512 reads for D. mexicanus remained for subsequent analyses. The Good's coverage index values were greater than $97 \%$ in all locations of both bark beetles (Table 1). 


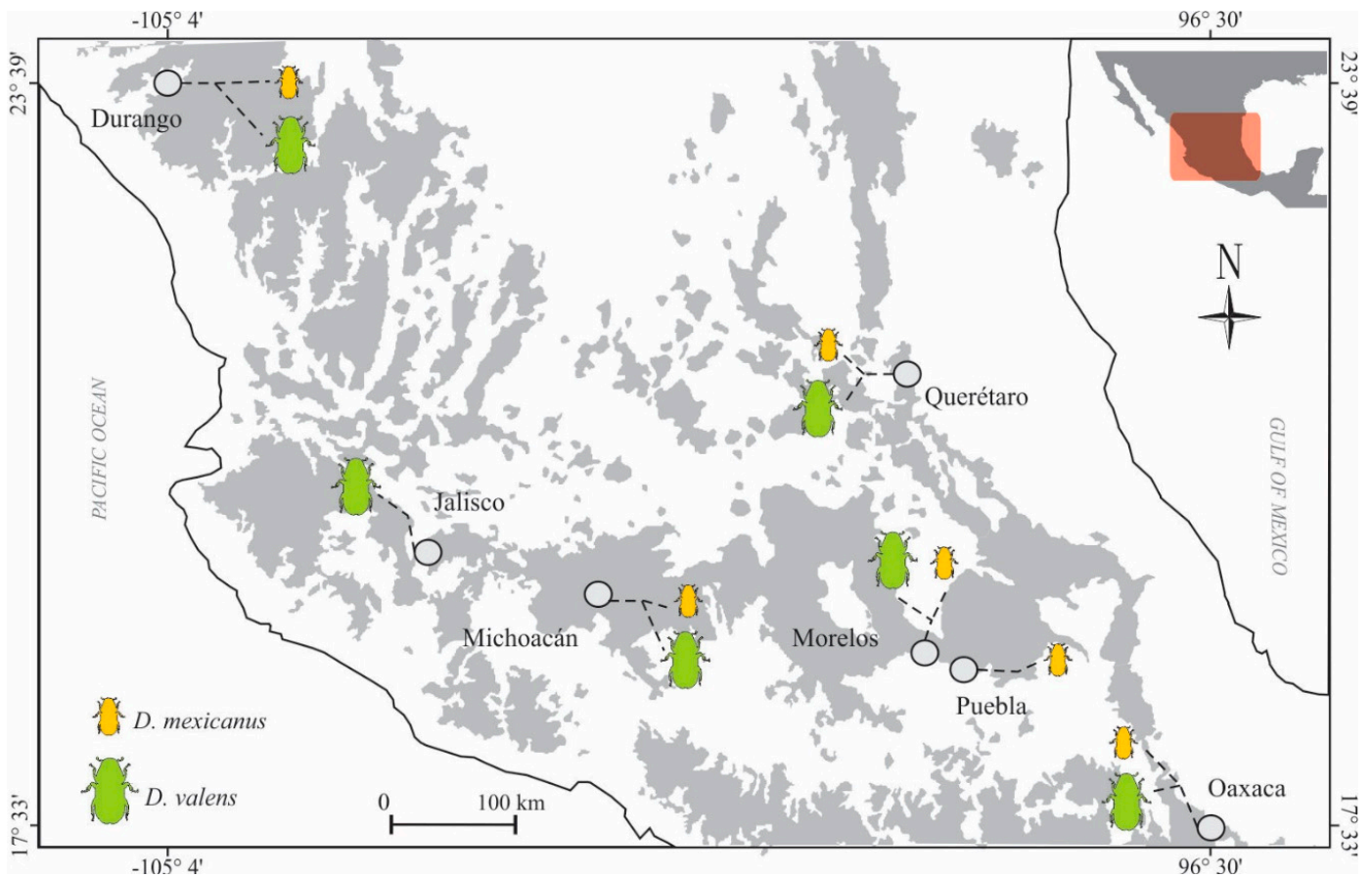

Figure 1. Locations studied of the Dendroctonus valens (green) and D. mexicanus (orange). Grey dot $=$ sampled localities; dot line $=$ collected species.

Table 1. Summary of pyrosequencing data and alpha diversity of Dendroctonus valens and D. mexicanus.

\begin{tabular}{|c|c|c|c|c|c|c|c|c|}
\hline \multirow{2}{*}{ Label } & \multirow{2}{*}{$\begin{array}{c}\text { No. of High } \\
\text { Quality } \\
\text { Reads }\end{array}$} & \multirow{2}{*}{$\begin{array}{c}\text { Observed } \\
\text { OTUs }^{97}\end{array}$} & \multicolumn{5}{|c|}{ Richness and Diversity Index } & \multirow{2}{*}{$\begin{array}{l}\text { Good's } \\
\text { Coverage }\end{array}$} \\
\hline & & & Chao1 & PD * & Shannon & Simpson & Simpson $^{-1}$ & \\
\hline \multicolumn{9}{|c|}{ D. valens } \\
\hline Oaxaca I & 8300 & 118 & 232 & 5.20 & 3.6 & 0.866 & 7.5 & 0.973 \\
\hline Oaxaca II & 2703 & 115 & 234 & 4.73 & 3.7 & 0.872 & 7.8 & 0.974 \\
\hline Queretaro I & 6403 & 173 & 371 & 5.64 & 4.7 & 0.930 & 14.3 & 0.960 \\
\hline Queretaro II & 13,305 & 158 & 364 & 5.79 & 4.9 & 0.944 & 17.8 & 0.965 \\
\hline Morelos I & 11,589 & 174 & 390 & 6.51 & 4.6 & 0.916 & 11.9 & 0.961 \\
\hline Morelos II & 5815 & 153 & 327 & 6.50 & 4.2 & 0.896 & 9.6 & 0.966 \\
\hline Jalisco I & 13,459 & 87 & 118 & 3.11 & 3.6 & 0.851 & 6.7 & 0.986 \\
\hline Jalisco II & 3713 & 164 & 314 & 4.94 & 4.5 & 0.899 & 9.9 & 0.965 \\
\hline Durango I & 8409 & 109 & 224 & 4.68 & 3.4 & 0.834 & 6.0 & 0.975 \\
\hline Durango II & 4723 & 158 & 251 & 5.41 & 4.2 & 0.898 & 9.8 & 0.968 \\
\hline Michoacan I & 3461 & 100 & 268 & 4.13 & 3.4 & 0.859 & 7.1 & 0.975 \\
\hline Michoacan II & 4469 & 117 & 196 & 5.59 & 3.5 & 0.861 & 7.2 & 0.975 \\
\hline \multicolumn{9}{|c|}{ D. mexicanus } \\
\hline Oaxaca I & 7310 & 95 & 143 & 3.68 & 4.0 & 0.899 & 9.9 & 0.981 \\
\hline Oaxaca II & 6836 & 60 & 95 & 2.27 & 2.5 & 0.748 & 4.0 & 0.988 \\
\hline Queretaro I & 4436 & 91 & 166 & 3.19 & 2.8 & 0.649 & 2.8 & 0.981 \\
\hline Queretaro II & 3589 & 73 & 104 & 1.95 & 3.3 & 0.789 & 4.7 & 0.989 \\
\hline Morelos I & 37,466 & 73 & 184 & 2.82 & 2.5 & 0.623 & 2.7 & 0.982 \\
\hline Morelos II & 4444 & 95 & 163 & 4.47 & 3.7 & 0.828 & 5.8 & 0.980 \\
\hline Puebla I & 4681 & 87 & 120 & 2.91 & 3.0 & 0.741 & 3.9 & 0.983 \\
\hline Puebla II & 2906 & 72 & 89 & 2.66 & 3.0 & 0.743 & 3.9 & 0.989 \\
\hline Durango I & 16,022 & 82 & 139 & 2.95 & 3.0 & 0.775 & 4.4 & 0.984 \\
\hline Durango II & 5786 & 65 & 83 & 2.10 & 3.2 & 0.798 & 4.9 & 0.990 \\
\hline Michoacan I & 3589 & 102 & 154 & 3.42 & 2.9 & 0.641 & 2.8 & 0.980 \\
\hline Michoacan II & 4447 & 97 & 125 & 4.14 & 3.5 & 0.770 & 4.3 & 0.985 \\
\hline
\end{tabular}

* PD: Phylogenetic Diversity. 
The gut bacterial communities were similar in composition and abundance among the locations of both bark beetles. The most abundant phylum in both species was Proteobacteria, followed by Firmicutes, Actinobacteria, and Deinococcus-Thermus (Figure 1). At the genus level, the most abundant were in Dendroctonus valens_Providencia (35\%), Enterobacter (31\%), Rahnella (13\%), Pseudomonas (4\%), Carnobacterium (4\%), Pantoea (3\%), Citrobacter (2\%), Klebsiella (2\%), Pectobacterium (1\%), Serratia (1\%), and Hafnia (1\%)-while in D. mexicanus, they were Erwinia (29\%), Serratia (23\%), Rahnella (11\%), Pseudomonas (8\%), Enterobacter (8\%), Providencia (6\%), Pantoea (5\%), Paenibacillus (3\%), Klebsiella (1\%), Kluyvera (1\%), Acinetobacter (1\%), and Yokenella (1\%). Other genera with $<1.0 \%$ relative abundances were found in both species (Figures 2 and 3).

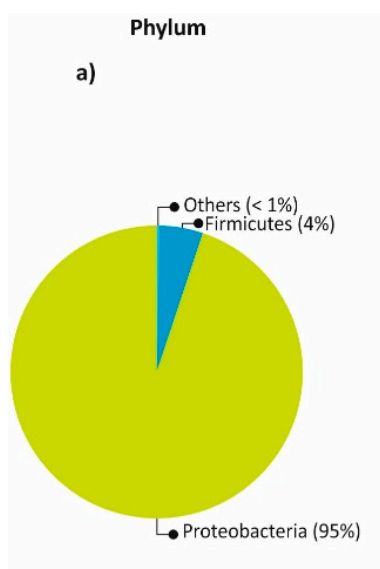

b)

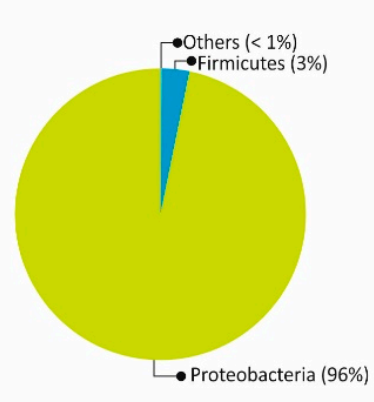

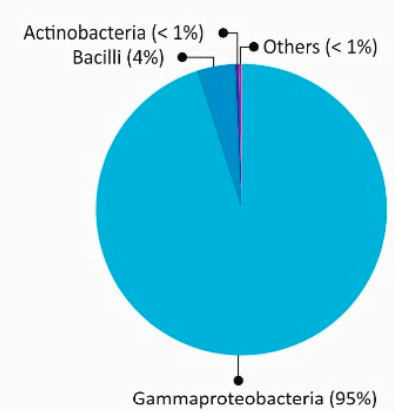

Gammaproteobacteria (95\%)

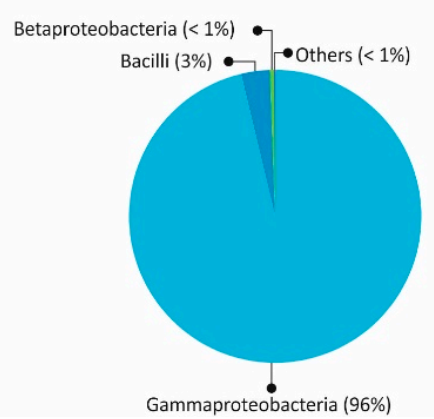

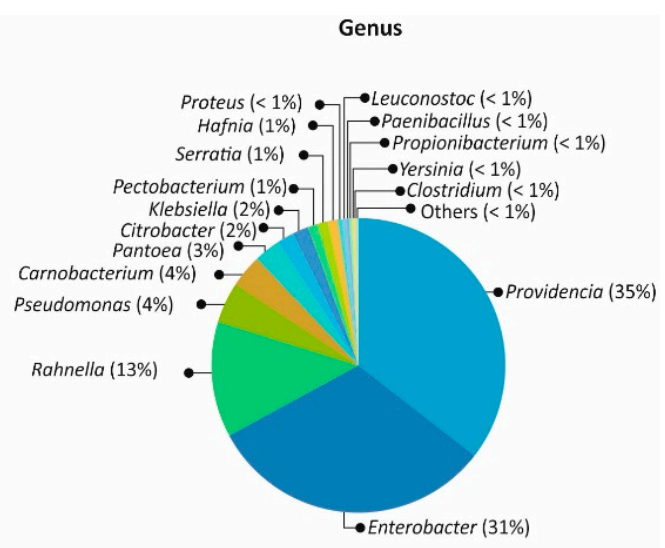

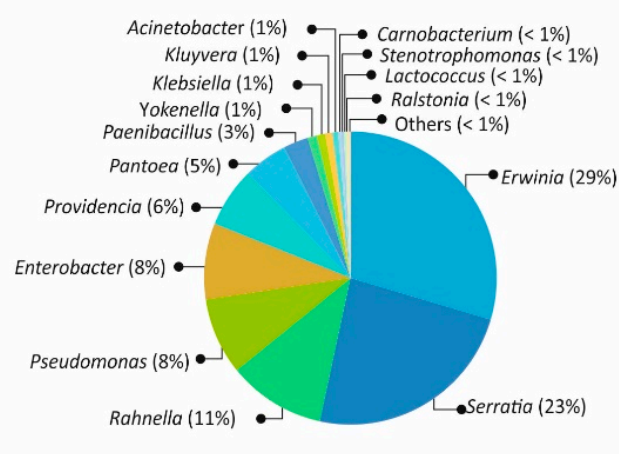

Figure 2. Relative abundances of the most abundant taxa of the gut at phylum, class, family, and genus levels: (a) Dendroctonus valens, (b) D. mexicanus. 


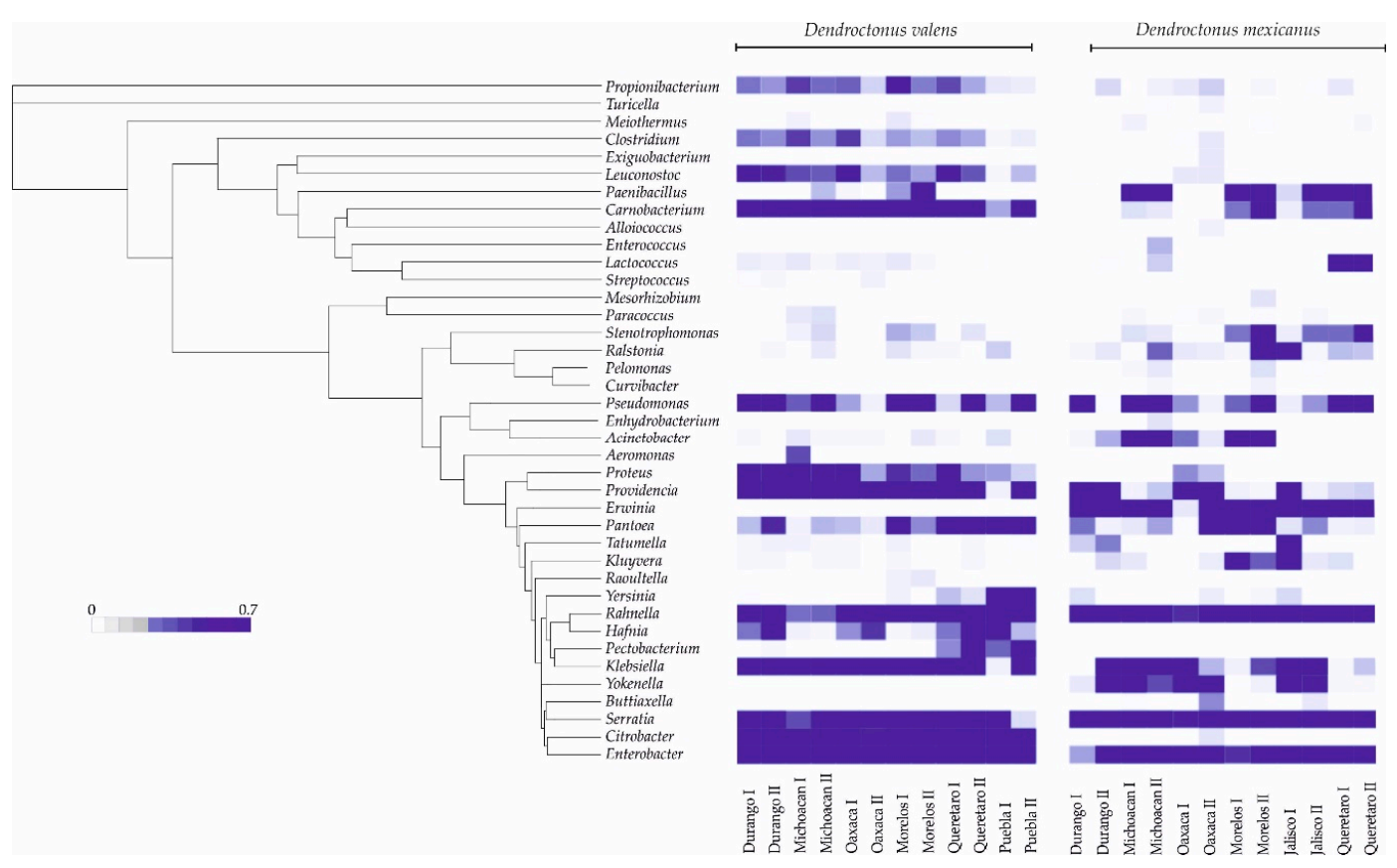

Figure 3. Heatmap of representative sequences of operational taxonomic units (OTUs) of Dendroctonus valens and D. mexicanus in different localities. The range of colors indicates the OTUs relative abundance for each sample; dark colors indicate higher abundance and light ones lower abundance.

\subsection{Bacterial Community Diversity}

The operational taxonomic units (OTUs) richness, evenness, and overall diversity of the bacteria were similar among localities in both bark beetles, except for the Michoacan locality in Dendroctonus valens. An average of 127 and 84.5 of the observed OTUs was recorded across locations for D. valens and D. mexicanus, respectively. The higher number of OTUs was detected in Morelos I (177) and Oaxaca I (102) for D. valens and D. mexicanus, respectively (Table 1).

The values of species richness (Chao1) were not statistically different among the locations of Dendroctonus mexicanus ( $F$ Welch test: $F_{\text {Chao } 1}=1.7, p=0.35$ ), but whether among $D$. valens localities ( $F$ Welch test: $F_{\text {Chao1 }}=130.8, p=0.003$ ) being only different the Michoacan location (Michoacan vs. Oaxaca; $p=0.02$ ). The values of the Shannon diversity index varied from 3.4 to 4.9 among the $D$. valens locations and from 2.5 to 4.0 in those of $D$. mexicanus. This index did not show differences among the $D$. mexicanus populations ( $F$ Welch test: $F_{\text {Shannon }}=0.17, p=0.95$ ), but whether among $D$. valens locations ( $F$ Welch test: $F_{\text {Shannon }}=15.9, p=0.03$ ) where the Michoacan locality was different to the Queretaro locality $(p=0.009)$. The values of the phylogenetic diversity (PD) index were not statistically different among locations of $D$. mexicanus ( $F$ Welch test: $F_{\mathrm{PD}}=0.84, p=0.6$ ) but whether among the D. valens locations $\left(F_{\mathrm{PD}}=16.9, p=0.03\right)$ where the Jalisco locality was different to the Morelos $(p=0.01)$. Lastly, the values of the Simpson (S) index did not show statistically significant differences among locations of the $D$. mexicanus ( $F$ Welch test: $F_{\mathrm{S}}=1.5, p=0.41$ ) but whether among the $D$. valens locations ( $F$ Welch test: $F_{\mathrm{S}}=13.7, p=0.04$ ) where the Michoacan locality was different from the Queretaro $(p=0.04 ;$ Table 1$)$.

The Dendroctonus valens localities shared a strict core bacteriome (Table S4) constituted by 10 bacterial genera, namely Citrobacter, Carnobacterium, Enterobacter, Hafnia, Klebsiella, Pantoea, Providencia, Pseudomonas, Rahnella, and Serratia, whose sequences represented $93.8 \%$ of the total reads. On the other hand, the D. mexicanus localities shared a strict core bacteriome (Table S4) constituted by eight taxa, namely Enterobacter, Erwinia, Pantoea, Pseudomonas, Providencia, Rahnella, Serratia, and Yokenella, representing $94 \%$ of the total reads. The Venn diagram built for both species based on 
all localities showed that only six bacterial genera-Enterobacter, Pantoea, Providencia, Pseudomonas, Rahnella, and Serratia—were shared among these bark beetles (Figure 4).

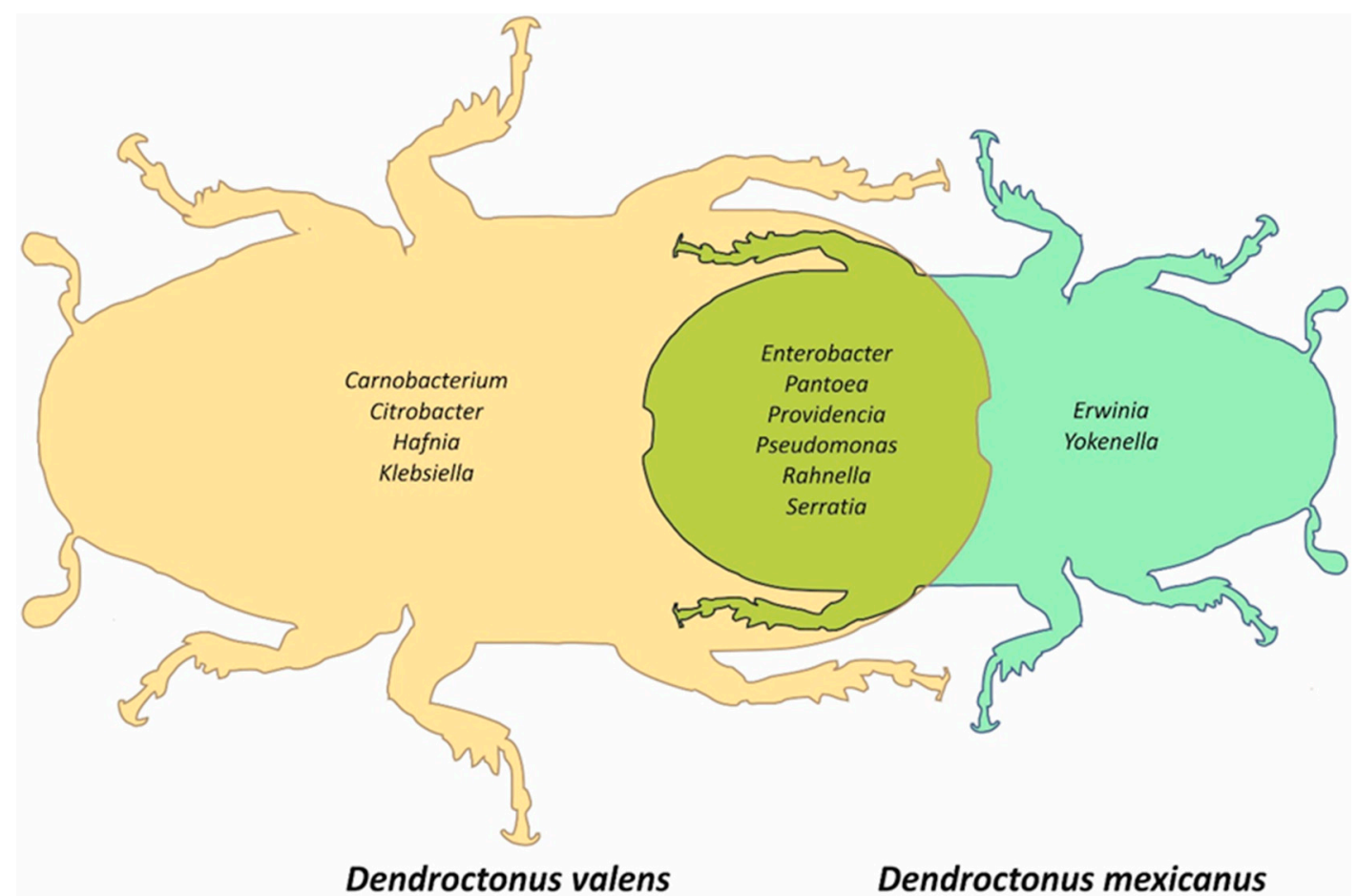

Figure 4. Venn diagram representing unique and shared taxa present in all localities between Dendroctonus valens and D. mexicanus.

The first three coordinates of the Principal Coordinates Analysis (PCoA) in Dendroctonus valens using weighted UniFrac ( $\mathrm{wU}$ ) and unweighted UniFrac (uwU) distances explained 96.9\% (PCo1-87.8\%; PCo2-4.8\%; PCo3-4.3\%) and 45.5\% (PCo1-21.6\%; PCo2-12.6\%; PCo3-11.3\%) of the total variation, respectively (Figure 5a,b). In D. mexicanus the PCoA (wU) explained $81.6 \%$ (PCo1-43.0\%; PCo2-24.8\%; PCo3-13.8\%) and the PCoA (uwU) 50.8\% (PCo1-20.3\%; PCo2-17.0\%; PCo3-13.5\%) of the total variation (Figure $5 c, d$ ). Significant differences were found in the bacterial $\beta$-diversity among the communities of different localities for both bark beetles using unweighted UniFrac with the Monte Carlo test (Table S2, $p<0.05$ ). These differences were mainly due to the presence or absence of rare taxa (e.g., Turicella, Meiothermus, Exiguobacterium, Curvibacter, among others), which have a relative frequency lower than $1 \%$ (Figure 3, light colors). Meanwhile, no significant differences were found among the bacterial communities of both Dendroctonus species when the relative abundance was weighted (Table S2, $p>0.05$ ). These significant differences in $\beta$-diversity of both Dendroctonus species were confirmed with the Adonis test using the pairwise Bray-Curtis dissimilarity matrices $\left(D\right.$. valens $p=0.001, R^{2}=0.85 ; D$. mexicanus $\left.p=0.006, R^{2}=0.71\right)$. 


\section{Dendroctonus valens}

a)

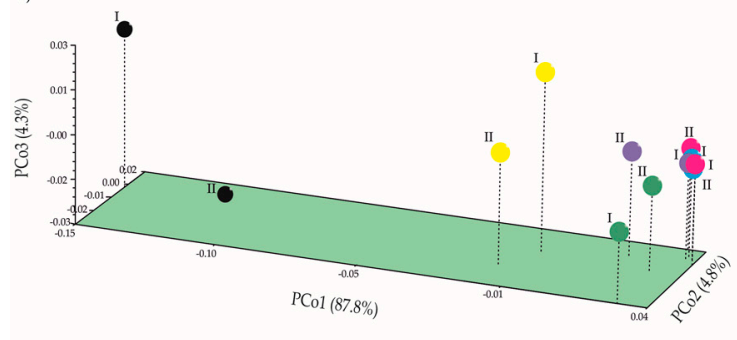

b)

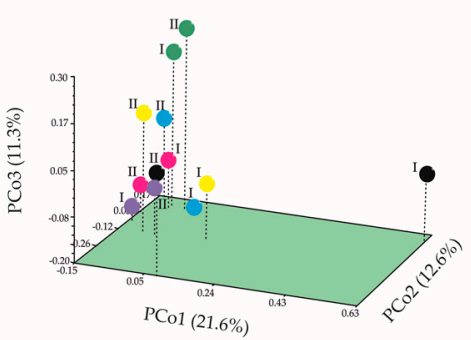

Dendroctonus mexicanus

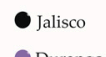

Durango

Queretaro

- Oaxaca

Michoacan Morelos Puebla
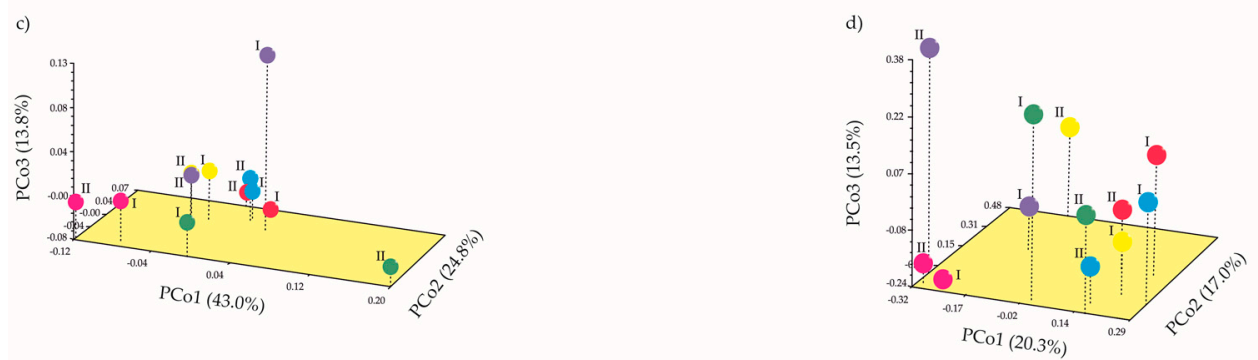

Figure 5. Principal coordinates analysis (PCoA) of bacterial communities of Dendroctonus valens $(\mathbf{a}, \mathbf{b})$ and D. mexicanus $(\mathbf{c}, \mathbf{d})$ using weighted and unweighted UniFrac distances, respectively. $\mathrm{I}=$ replicate one; II = replicate two.

Lastly, the correlation between the pairwise phylogenetic distance (wU and uwU distances) of bacterial communities and the pairwise geographical distance of locations of each bark beetle using the Mantel test were not significant at the geographical space analyzed $\left(\mathrm{RMA}_{\mathrm{s}} r_{\mathrm{s}}=0.07-0.11, p_{\mathrm{s}}>0.05\right.$, Table S3).

\subsection{Prediction Roles of Gut Bacterial Communities}

Based on 79,349 and 92,660 reads for Dendroctonus valens and D. mexicanus, respectively, the predictive analyzes of the microbiota in the Kyoto Encyclopedia of Genes and Genomes (KEGG) pathways at level 2 (Figure 6) revealed a total of 195 metabolic pathways for gut bacterial communities for the former species and 203 for the latter. The Nearest Sequenced Taxon Index (NSTI) values varied from 0.020 to $0.031(0.023 \pm 0.003$ standard deviation, $S D)$ in $D$. valens locations, whereas these varied from 0.018 to $0.13(0.064 \pm 0.041 \mathrm{SD})$ in $D$. mexicanus locations, indicating accurate metabolic predictions of the bacterial metagenome of both bark beetles. The heatmap, based on the whole gut bacterial communities of each bark beetle, revealed the presence of genes putatively important for amino acid, carbohydrate, and vitamin metabolism (Figure 6). 


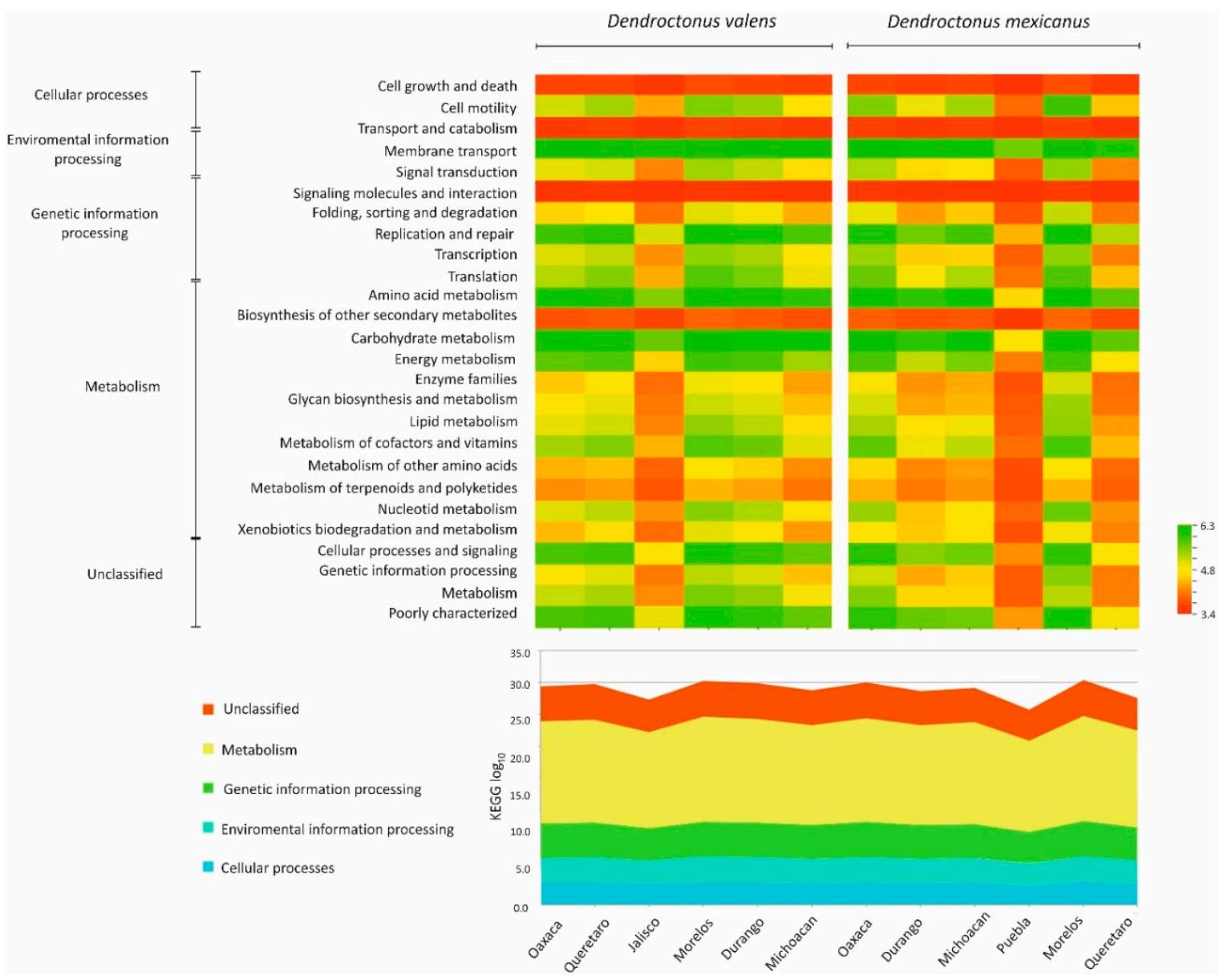

Figure 6. Heatmap of PICRUSt-inferred genes of bacterial communities of Dendroctonus valens and D. mexicanus. The range of colors indicates the relative abundance of metabolic pathways for each sample. Dark colors (green and yellow) indicate higher abundance and light (orange and red) ones lower abundance. The dendrogram shows the dissimilarities between the potential metabolic pathways of different bacterial communities clustered in KEGG 2 level. The relative abundance of the most important metabolic pathways in the KEGG 1 level on a $\log _{10}$ scale is shown below the heatmap figure.

The ANOSIM test did not show statistically significant differences among metabolic pathways of bacterial communities of $D$. valens $(R=-0.18, p>0.05)$ and $D$. mexicanus $(R=-0.23, p>0.05)$ across the geographical locations.

\section{Discussion}

One of the poorly studied aspects about the bacterial communities in insects, including bark beetles, is whether their structure (i.e., the composition and abundance of their members) and function (metabolic pathways) change across geographic space [41,42]. Our findings show that the gut bacterial community structure of bark beetles Dendroctonus valens and D. mexicanus is apparently stable across the geographical locations, as suggested by the values of richness and diversity indices that did not show significant differences among localities, except the Michoacan location in D. valens, whose geographical distance to its nearest pair (Jalisco) is $160.2 \mathrm{~km}$ and to its furthest pair (Oaxaca) the $608.2 \mathrm{~km}$ (Figure 1).

These findings agree with those reported for the microbial communities in the pine weevil Hylobious abietis, which are similar at lower taxonomic levels (family and genus) across locations in Europe [32], but they were different from those reported for Dendroctonus valens from different geographical sites in the United States of America [23]. Whereas it is difficult to recognize the factors that can drive these differences in $D$. valens, some of them may be the number of insects sampled, 
the anatomical site analyzed (whole insects, tree host, gut, exoskeleton, mycangium), the methodology employed (molecular cloning, DGGE or Next Generation Sequencing (NGS) methodologies), and the geographical scale studied.

The Venn diagram shows that the Dendroctonus species have an intraspecific core bacteriome different in genera number (Figure 4) and relative abundance (Figure 2). However, despite these differences, they share a minimal number of genera, among which stand out Enterobacter, Pantoea, Providencia, Pseudomonas, Rahnella, and Serratia (Figure 4). This small group of bacterial genera is the same as those reported for the Dendroctonus species [28], indicating that the intraspecific core bacteriome of these bark beetles, and perhaps of each Dendroctonus species, is higher than the interspecific core bacteriome reported for Dendroctonus. Based on these results, we hypothesize that each Dendroctonus species may have a specific core bacteriome, which can include all or almost all the members of the interspecific core bacteriome known to the Dendroctonus genus [28]. This closed group may support the basic metabolic functions of these bark beetles independent of the number of localities sampled and geographical space analyzed, as reported in other studies [32].

Our findings regarding $\beta$-diversity with unweighted UniFrac show that bacterial communities of both bark beetles vary geographically. The PCoA (uwU) and heatmap (Figures 3 and $5 b, d$ ) show that this variation in both bark beetles is a result of the presence or absence of rare members with low relative abundance ( $<1 \%$ reads), as well as due to some dominant genera. In fact, some members of the intraspecific core bacteriome of these bark beetles are not necessarily the most abundant within the community, and their relative abundance varies among locations. This same pattern in the variation of $\beta$-diversity, given by the less-frequent members, has been observed in other studies carried out in other scolytines [3,26-28,32].

Our Mantel test results indicate that the spatial variation of gut bacterial communities in both bark beetles is not associated with the geographic distance, suggesting that the dominant genera ( $>1 \%$ relative abundance), including the strict core bacteriome members of both bark beetles, are present in all the geographical localities analyzed. Our findings agree with those reported for the pine weevil Hylobius abietis [32] but not with those reported for Dendroctonus valens at a wider geographical space [23]. This difference observed in D. valens with respect to geographical distance may be explained by the different geographical distances analyzed and the statistical coverage of the techniques used. In this study, we used NGS technologies and the maximum geographical distance between the sites was $1175 \mathrm{~km}$, but Adams et al. [23] used the DGGE technique, and the maximum distance between their localities was $2500 \mathrm{~km}$.

The factors that influence the structure to the bacterial communities should be determined in further studies. As suggested for other insects [43-45] and some Dendroctonus species [21,31,46], it is possible that geographical distance is not an important factor that influences these differences, particularly considering that pine-associated endophytic bacterial communities are highly similar and independent of their geographical location $[38,47,48]$.

In addition, it is known that the gut is a micro-environmentally heterogeneous habitat and hence limiting for many bacteria, where the prevalence or not of specific bacteria within this system is not random [49]. In the case of bark beetles' guts, different ecological and demographic factors (e.g., interactions, competition, population growth, resource availability) may determine the presence and/or dominance of bacterial groups and mutualistic relationships between them, at least between members of the bacteriome. Moreover, when the physiological conditions in the gut of bark beetles change, the pathogenic or commensal capacities of some bacteria may be expressed in this system [50].

Independent of the absence or presence of members at low frequency, the metabolic pathways inference analyzes with PICRUSt suggest that the basic biochemical functions of the microbiota and their contribution to the host biology are apparently conserved. In fact, whereas a considerable number of functional metabolic pathways were predicted for the gut bacterial communities of both the Dendroctonus species, the most important metabolic pathways were those related to nutrition and detoxification. Of these, carbohydrate metabolism, cofactors, and vitamins, as well as the biodegradation and 
metabolism of terpenoids and xenobiotic compounds were the most frequent. These functions are fundamental because these bark beetles feed on a substrate rich in organic compounds, non-essential amino acids, and structural carbohydrates, such as hemicellulose and cellulose, that are not easily degraded by insects. Additionally, throughout their entire life cycle, bark beetles are in contact with plant defensive compounds, some highly toxic, such as limonene and pinene, that can cause cellular damage and kill the Dendroctonus species [51-53]. Lastly, future studies using metatranscriptomics are necessary to confirm these inferences based on the 16S rRNA gene because to the best of our knowledge, there are no associative studies between the taxonomy assignments using this gene and specific functional pathways or genes in the Dendroctonus species, further, the results generated from this research using next-generation sequencing could expand knowledge for the control and management of these bark beetles.

\section{Materials and Methods}

\subsection{Insect Collection, Dissection and DNA Extraction}

Emerged adults of $D$. valens and D. mexicanus were directly collected from naturally infested pine trees in six distinct geographical locations in Mexico during 2017 (Figure 1, Table S1). The largest geographical distance between localities was $1175 \mathrm{~km}$ (Durango-Oaxaca sites), and the shortest distance was $160 \mathrm{~km}$ (Morelos-Puebla sites). Insects were removed from their galleries using fine sterile forceps, placed in sterile polycarbonate containers with wet paper to avoid insect desiccation, stored at $4{ }^{\circ} \mathrm{C}$ for their transport, and processed immediately after arriving at the laboratory.

Two sets of 30 insects each were taken in each locality, to integrate two biological replicates for each Dendroctonus species. The insects were dissected under sterile conditions as described by Briones-Roblero et al. [9]. The last washing water was inoculated in Petri dishes with trypticase soy agar (TSA, BD, Difco, Sparks, MD, USA) inoculated with the last rinsing water and by negative Polymerase Chain Reaction (PCR) amplification of the same water to assess the efficiency of the disinfestation. The plates were incubated at $28^{\circ} \mathrm{C}$ for $48-72 \mathrm{~h}$. Each set of 30 guts was processed independently for DNA extraction with DNeasy Blood and Tissue Kit (Qiagen, Valencia, CA, USA) according to the manufacturer's protocol.

\subsection{Bacterial $16 S$ rRNA Polymerase Chain Reaction Amplification and Pyrosequencing}

The V1-V3 region of the $16 \mathrm{~S}$ rRNA gene was amplified using universal primers 8F and 556R [54], fitted to $10 \mathrm{bp}$ multiplex identifiers (MID) and Roche 454 adaptors for the Lib-L protocol. PCR reactions were performed in a thermal cycler Techne TC 5000 (Techne, Staffordshire, UK) in a final volume of $25 \mu \mathrm{L}$ containing $80 \mathrm{ng}$ DNA template, $1 \times$ reaction buffer, $2.0 \mathrm{mM} \mathrm{MgCl} 2,0.4 \mathrm{pM}$ of each primer, $0.4 \mathrm{mM}$ of each dNTPs, and 1.0 U of Platinum Taq DNA polymerase High Fidelity (Invitrogen ${ }^{\mathrm{TM}}$ Life Sciences, Carlsbad, CA, USA). The reaction conditions were as follows: initial denaturation at $94{ }^{\circ} \mathrm{C}$ for $5 \mathrm{~min}, 25$ cycles denaturation at $94{ }^{\circ} \mathrm{C}$ for $50 \mathrm{~s}$, annealing temperature $53^{\circ} \mathrm{C}$ for $50 \mathrm{~s}$ and extension at $72{ }^{\circ} \mathrm{C}$ for $50 \mathrm{~s}$, and a final extension $72{ }^{\circ} \mathrm{C}$ for $5 \mathrm{~min}$.

The amplification products of three individual PCR reactions for each biological replicate were combined and purified using a QIAquick Gel Extraction kit (Qiagen, Valencia, CA, USA). The amplicons of all samples were pooled in equal volumes for pyrosequencing using a Roche GS-FLX Titanium 454 pyrosequencer (Roche, Mannheim, Germany) in Macrogen Inc. (Seoul, Korea).

\subsection{Data Pyrosequencing Analysis}

The data analysis was conducted using the software Quantitative Insight into Microbial Ecology (QIIME) v 1.9 (available online: http:/ / qiime.org) [55]. All low-quality reads (Phred quality score $<25$ ) and sequences $<200$ or $>550 \mathrm{bp}$ long containing ambiguous characters, homopolymers $>6 \mathrm{bp}$, and mismatches in primers $>1$ were removed from subsequent analyzes [56]. 
The high-quality sequences were grouped in OTUs through the open-reference picking method at a 97\% similarity threshold [57] using Uclust v 1.2.22 [58]. Chimeric sequences were identified with Chimera Slayer v 1.39.5.0 [59] and then removed from the data set. The most abundant read of each OTU was selected as a representative sequence and then aligned with the Greengenes core sequences set (available online: http:/ / greengenes.lbl.gov/) using PyNast [60].

The taxonomic assignment from phylum to genus for representative sequences was done at a $\geq 0.8$ confidence score with the Ribosomal Database Project (RDP) Classifier (available online: https:/ / rdp. cme.msu.edu/index.jsp) to know its taxonomic identity [61]. The taxonomic assignment was manually corroborated by comparing with the closest matched sequences on three databases (RDP, GenBank, and Greengenes), the cutoff being from $97 \%$ to $100 \%$ at the genus level. A Maximum-Likelihood (ML) phylogenetic inference analysis was performed in PhyML (available online: http:/ /atgc.lirmm.fr/ phyml/), using only representative sequences at the genus level. To this analysis, these sequences were aligned in Clustal X v 2.0.10 (available online: http://www.clustal.org/clustal2/) [62] and trimmed at their $5^{\prime}$ and $3^{\prime}$ ends in SeaView v 4 (available online: ftp://pbil.univ-lyon1.fr/pub/ mol_phylogeny/seaview/archive/). The best-fit model of nucleotide substitution was selected with JModeltest v 2.1.7 (available online: http:/ / darwin.uvigo.es/our-software/) [63] based on the Akaike Information Criterion (AIC). The reliability of each node was estimated via a bootstrap analysis after 1000 pseudoreplicates. Finally, the phylogeny and heatmap of relative abundances were matched using Interactive Tree of Life (iTol) (available online: https:/ /itol.embl.de/) [64].

\subsection{Bacterial Diversity Analysis}

As the amount of sequences analyzed could affect the diversity analysis, we used rarefied data running the multiple rarefaction script implemented in QIIME v 1.9 (for each sample, we calculated the number of OTUs expected to be observed for 100 reads). To determine the probability that a randomly selected amplicon from a sample was previously sequenced, the Good's coverage was calculated as an estimator of sampling completeness [65]. Estimators of richness (Chao1), diversity (Simpson and Shannon), and phylogenetic diversity (PD) were used to determine the $\alpha$-diversity in bacterial communities for each bark beetle species and biological replicates [66,67]. The normality and homogeneity of the variances of these estimators were tested with a Shapiro-Wilkinson test and $F$ test [68]. As the diversity indices did not meet the assumptions of equal variances, those values were compared using Welch's $F$ test for ANOVAs and its respective post hoc multiple paired comparisons using Dunn's test [69].

The $\beta$-diversity of gut bacterial communities among locations was estimated using unweighted (considers only phylogenetic richness) and weighted (considers both relative abundance and phylogenetic richness) Fast UniFrac distances [70], as well as the Bray-Curtis dissimilarity index [71]. The Monte Carlo method was performed to test the statistically significant differences among the bacterial communities using both Fast UniFrac distances [70], while the Adonis test was used to evaluate the differences with Bray-Curtis distances. A Principal Coordinate Analysis (PCoA) using unweighted and weighted UniFrac distances was performed in NTSYS-PC v 2.02 (Exeter Software, Setauket, New York, NY, USA) to explore multidimensional patterns of diversity variation of bacterial communities among locations [72].

\subsection{Core Bacteriome}

The strict core bacteriome of these bark beetles was determined according to Hernández-García et al. [28]. We, only include those bacterial genera present in all localities and their replicates, whose relative frequencies were $>1 \%$. To identify unique and shared OTUs among localities of both the Dendroctonus species, a Venn diagram was generated in Bioinformatics and Evolutionary Genomics (available online: http://bioinformatics.psb.ugent.be/webtools/Venn/).

To determine the variation of bacterial communities of each bark beetle with respect to geographical distance, a nonparametric Mantel test was used to determine the correlation between the 
matrix of pairwise geographic distance among localities and pairwise phylogenetic distance matrix, using both weighted and unweighted UniFrac [73]. The randomized matrices were generated by row and column permutation. The randomization was performed 5000 times to establish a $95 \%$ confidence interval [73]. However, given that the estimation and measurement of the correlation test between the geographic and phylogenetic distance matrices of bacterial communities were not free of errors, it was necessary to estimate the slope and $y$-intercept to find the best straight line that described this association in a confinable way. To do this, we used the reduced major axis (RMA) method and 95\% confidence intervals for elements of the line that were calculated using a bootstrap test as implemented on PAST v 3.20 (available online: https:/ / folk.uio.no/ohammer/past/) [69].

\subsection{Predictive Functional Analysis Based on Metagenomic $16 S$ rRNA Surveys}

The predicted functional profiles of bacterial communities associated with the gut of $D$. valens and D. mexicanus of each locality were inferred with the bioinformatic tool PICRUSt [74]. The sequences from each library were demultiplexed and used to generate the OTU table in BIOM format, following a closed-reference method. Given that the ability of PICRUSt to estimate a metabolic profile relies on a set of known sequenced genomes, the OTU table was normalized and used to make a comparison with sequenced bacterial genomes deposited in the Kyoto Encyclopedia of Genes and Genomes (KEGG) [75] at hierarchical levels 2 and 3.

The obtained tables with the counts of predicted genes per sample were cleaned according to the following criteria: Removal of categories unrelated to bacterial physiology/metabolism (similar to human diseases) and removal of gene family categories with a count equal to zero. The functional predictions were plotted at the hierarchical levels 2 and 3 of KEGG. To evaluate the prediction accuracy of samples, we calculated the Nearest Sequenced Taxon Index (NSTI). The NSTI scores summarize the extent to which microorganisms in a sample are related to sequences' genomes, and they represent the average branch length that separates each OTU from a reference bacterial genome, weighting their relative abundance in each sample [74]. Lastly, to compare whether the metabolic pathways among the gut bacterial communities of different locations of both the Dendroctonus species were different, we performed an analysis of similarity (ANOSIM) using a Gower index with 10,000 permutations in PAST v 3.20 [69].

\subsection{Data Accessibility}

The pyrosequencing-derived 16S rRNA gene sequence datasets were submitted to the NCBI database, under accession number of Sequence Read Archive (SRA) SRP158467.

Supplementary Materials: Supplementary Materials can be found at http:/ /www.mdpi.com/1422-0067/19/9/ 2578/s1.

Author Contributions: Conceptualization, G.Z. and F.N.R.-O.; Methodology, J.A.H.-G. and C.I.B.-R.; Formal Analysis, J.A.H.-G., R.G.-E., C.I.B.-R., C.C.-R., F.N.R.-O., G.Z.; Writing-Original Draft Preparation, J.A.H.-G., F.N.R.-O., G.Z.; Writing-Review \& Editing, J.A.H.-G., R.G.-E., C.I.B.-R., C.C.-R., F.N.R.-O., G.Z.; Visualization, J.A.H.-G.; Supervision, G.Z.; Funding Acquisition, G.Z. and F.N.R.-O.

Funding: This research was partially funded by Consejo Nacional de Ciencia y Tecnología (CONACyT 169494/CB2011) and Red Temática en Salud Forestal (RTSF) from CONACyT.

Acknowledgments: This work was part of J.A.H.-G. Ph.D. dissertation. J.A.H.-G., R.G.-E., C.I.B.-R. were fellows of CONACyT $(369256,275347,227280)$ and of the program of Beca de Estimulo Institucional de Formación de Investigadores del Instituto Politécnico Nacional (BEIFI-IPN). We appreciate and thank the comments of anonymous reviewers.

Conflicts of Interest: The authors declare no conflict of interest. 


\section{Abbreviations}

$\begin{array}{ll}\text { AIC } & \text { Akaike Information Criterion } \\ \text { ANOVA } & \text { Analysis of Variance } \\ \text { DGGE } & \text { Denaturing Gradient Gel Electrophoresis } \\ \text { KEGG } & \text { Kyoto Encyclopedia of Genes and Genomes } \\ \text { NGS } & \text { Next Generation Sequencing } \\ \text { NSTI } & \text { Nearest Sequenced Taxon Index } \\ \text { NTSYS-PC } & \text { Numerical Taxonomy and Multivariate Analysis } \\ \text { OTU } & \text { Operational Taxonomic Unit } \\ \text { PCoA } & \text { Principal Coordinate Analysis } \\ \text { PD } & \text { Phylogenetic Diversity } \\ \text { PICRUSt } & \text { Phylogenetic Investigation of Communities by Reconstruction of Unobserved States } \\ \text { QIIME } & \text { Quantitative Insight into Microbial Ecology } \\ \text { RDP } & \text { Ribosomal Database Project } \\ \text { uwU } & \text { Unweighted UniFrac } \\ \text { wU } & \text { Weighted UniFrac }\end{array}$

\section{References}

1. Wood, S.L. The bark and ambrosia beetles of North and Central America (Coleoptera: Scolytidae), a taxonomic monograph. Great Basin Nat. Mem. 1982, 6, 1-1356.

2. Bentz, B.J.; Régnière, J.; Fettig, C.J.; Hansen, E.M.; Hayes, J.L.; Hicke, J.A.; Seybold, S.J. Climate change and bark beetles of the western United States and Canada: Direct and indirect effects. BioScience 2010, 60, 602-613. [CrossRef]

3. Six, D.L. The bark beetle holobiont: Why microbes matter. J. Chem. Ecol. 2013, 39, 989-1002. [CrossRef] [PubMed]

4. Davis, S.T. The ecology of yeasts in the bark beetle holobiont: A century of research revisited. Microb. Ecol. 2015, 69, 723-732. [CrossRef] [PubMed]

5. Six, D.L.; Bracewell, R. Dendroctonus. In Bark Beetles; Vega, F.E., Hofstetter, R.W., Eds.; Academic Press: San Diego, CA, USA, 2015; pp. 305-350.

6. Hofstetter, R.W.; Dinkins-Bookwalter, J.; Davis, T.S.; Klepzig, K.D. Symbiotic associations of bark beetles. In Bark Beetles; Vega, F.E., Hofstetter, R.W., Eds.; Academic Press: San Diego, CA, USA, 2015; pp. $209-245$.

7. Morales-Jiménez, J.; Zúñiga, G.; Ramírez-Saad, H.C.; Hernández-Rodríguez, C. Gut-associated bacteria throughout the life cycle of the bark beetle Dendroctonus rhizophagus Thomas and Bright (Curculionidae: Scolytinae) and their cellulolytic activities. Microb. Ecol. 2012, 64, 268-278. [CrossRef] [PubMed]

8. Hu, X.; Yu, J.; Wang, C.; Chen, H. Cellulolytic bacteria associated with the gut of Dendroctonus armandi larvae (Coleoptera: Curculionidae: Scolytinae). Forests 2014, 5, 455-465. [CrossRef]

9. Briones-Roblero, C.I.; Rodríguez-Díaz, R.; Santiago-Cruz, J.A.; Zúñiga, G.; Rivera-Orduña, F.N. Degradation capacities of bacteria and yeasts isolated from the gut of Dendroctonus rhizophagus (Curculionidae: Scolytinae). Folia Microbiol. 2017, 62, 1-9. [CrossRef] [PubMed]

10. Ayres, M.P.; Wilkens, R.T.; Ruel, J.J.; Lombardero, M.J.; Vallery, E. Nitrogen budgets of phloem-feeding bark beetles with and without symbiotic fungi. Ecology 2000, 81, 2198-2210. [CrossRef]

11. Bridges, J.R. Nitrogen-fixing bacteria associated with bark beetles. Microb. Ecol. 1981, 7, 131-137. [CrossRef] [PubMed]

12. Morales-Jiménez, J.; Zúñiga, G.; Villa-Tanaca, L.; Hernández-Rodríguez, C. Bacterial community and nitrogen fixation in the red turpentine beetle, Dendroctonus valens LeConte (Coleoptera: Curculionidae: Scolytinae). Microb. Ecol. 2009, 58, 879-891. [CrossRef] [PubMed]

13. Morales-Jiménez, J.; Vera-Ponce de León, A.; García-Domínguez, A.; Martínez-Romero, E.; Zúñiga, G.; Hernández-Rodríguez, C. Nitrogen-fixing and uricolytic bacteria associated with the gut of Dendroctonus rhizophagus and Dendroctonus valens (Curculionidae: Scolytinae). Microb. Ecol. 2013, 66, 200-210. [CrossRef] [PubMed] 
14. Boone, C.K.; Keefover-Ring, K.; Mapes, A.C.; Adams, A.S.; Bohlmann, J.; Raffa, K.F. Bacteria associated with a tree-killing insect reduce concentrations of plant defense compounds. J. Chem. Ecol. 2013, 39, 1003-1006. [CrossRef] [PubMed]

15. Adams, A.S.; Aylward, F.O.; Adams, S.M.; Erbilgin, N.; Aukema, B.H.; Currie, C.R.; Suen, G.; Raffa, K.F. Mountain pine beetles colonizing historical and naïve host trees are associated with a bacterial community highly enriched in genes contributing to terpene metabolism. Appl. Environ. Microbiol. 2013, 79, 3468-3475. [CrossRef] [PubMed]

16. Xu, L.T.; Lu, M.; Sun, J.H. Invasive bark beetle-associated microbes degrade a host defensive monoterpene. Insect Sci. 2016, 23, 183-190. [CrossRef] [PubMed]

17. Xu, L.; Shi, Z.; Wang, B.; Lu, M.; Sun, J.H. Pine defensive monoterpene-pinene influences the feeding behavior of Dendroctonus valens and its gut bacterial community structure. Int. J. Mol. Sci. 2016, 17, 1734. [CrossRef] [PubMed]

18. Cardoza, Y.J.; Klepzig, K.D.; Raffa, K.F. Bacteria in oral secretions of an endophytic insect inhibit antagonistic fungi. Ecol. Entomol. 2006, 31, 636-645. [CrossRef]

19. Scott, J.J.; Oh, D.-C.; Yuceer, M.C.; Klepzig, K.D.; Clardy, J.; Currie, C.R. Bacterial protection of beetle-fungus mutualism. Science 2008, 322, 63. [CrossRef] [PubMed]

20. Zhou, F.; Lou, Q.; Wang, B.; Xu, L.; Cheng, C.; Lu, M.; Sun, J. Altered carbohydrates allocation by associated bacteria-fungi interactions in a bark beetle-microbe symbiosis. Sci. Rep. 2016, 6, 20135. [CrossRef] [PubMed]

21. Vasanthakumar, A.; Delalibera, I.J.; Handelsman, J.; Klepzig, K.D.; Schloss, P.D.; Raffa, K.F. Characterization of gut-associated bacteria in larvae and adults of the southern pine beetle, Dendroctonus frontalis Zimmermann. Environ. Entomol. 2006, 35, 1710-1717. [CrossRef]

22. Yilmaz, H.; Sezen, K.; Kati, H.; Demirbağ, Z. The first study on the bacterial flora of the European spruce bark beetle, Dendroctonus micans (Coleoptera: Scolytidae). Biologia 2006, 61, 679-686. [CrossRef]

23. Adams, A.S.; Adams, S.M.; Currie, C.R.; Gillette, N.E.; Raffa, K.F. Geographic variation in bacterial communities associated with the red turpentine beetle (Coleoptera: Curculionidae). Environ. Entomol. 2010, 39, 406-414. [CrossRef] [PubMed]

24. Yaman, M.; Ertürk, Ö.; Aslan, I. Isolation of some pathogenic bacteria from the great spruce bark beetle, Dendroctonus micans and its specific predator, Rhizophagus grandis. Folia Microbiol. 2010, 55, 35-38. [CrossRef] [PubMed]

25. Muratoglu, H.; Sezen, K.; Demirbag, Z. Determination and pathogenicity of the bacterial flora associated with the spruce bark beetle, Ips typographus (L.) (Coleoptera: Curculionidae: Scolytinae). Turk. J. Biol. 2011, 35, 9-20. [CrossRef]

26. Durand, A.A.; Bergeron, A.; Constant, P.; Buffet, J.P.; Déziel, E.; Guertin, C. Surveying the endomicrobiome and ectomicrobiome of bark beetles: The case of Dendroctonus simplex. Sci. Rep. 2015, 5, 17190. [CrossRef] [PubMed]

27. Dohet, L.; Grégoire, J.C.; Berasategui, A.; Kaltenpoth, M.; Biedermann, P.H. Bacterial and fungal symbionts of parasitic Dendroctonus bark beetles. FEMS Microbiol. Ecol. 2016, 92, fiw129. [CrossRef] [PubMed]

28. Hernández-García, J.A.; Briones-Roblero, C.I.; Rivera-Orduña, F.N.; Zúñiga, G. Revealing the gut bacteriome of Dendroctonus bark beetles (Curculionidae: Scolytinae): Diversity, core members and co-evolutionary patterns. Sci. Rep. 2017, 7, 13864. [CrossRef] [PubMed]

29. Mason, C.J.; Hanshew, A.S.; Raffa, K.F. Contributions by host trees and insect activity to bacterial communities in Dendroctonus valens (Coleoptera: Curculionidae) galleries, and their high overlap with other microbial assemblages of bark beetles. Environ. Entomol. 2015, 45, 348-356. [CrossRef] [PubMed]

30. Briones-Roblero, C.I.; Hernández-García, J.A.; Gonzalez-Escobedo, R.; Soto-Robles, L.V.; Rivera-Orduña, F.N.; Zúñiga, G. Structure and dynamics of the gut bacterial microbiota of the bark beetle, Dendroctonus rhizophagus (Curculionidae: Scolytinae) across their life stages. PLoS ONE 2017, 12, e0175470. [CrossRef] [PubMed]

31. Hu, X.; Wang, C.; Chen, H.; Ma, J. Differences in the structure of the gut bacteria communities in development stages of the Chinese white pine beetle (Dendroctonus armandi). Int. J. Mol. Sci. 2013, 14, 21006-21020. [CrossRef] [PubMed]

32. Berasategui, A.; Axelsson, K.; Nordlander, G.; Schmidt, A.; Borg-Karlson, A.K.; Gershenzon, J.; Terenius, O.; Kaltenpoth, M. The gut microbiota of the pine weevil is similar across Europe and resembles that of other conifer-feeding beetles. Mol. Ecol. 2016, 25, 4014-4031. [CrossRef] [PubMed] 
33. Grünwald, S.; Pilhofer, M.; Höll, W. Microbial associations in gut systems of wood-and bark-inhabiting longhorned beetles [Coleoptera: Cerambycidae]. Syst. Appl. Microbiol. 2010, 33, 25-34. [CrossRef] [PubMed]

34. Russell, J.A.; Moreau, C.S.; Goldman-Huertas, B.; Fujiwara, M.; Lohman, D.J.; Pierce, N.E. Bacterial gut symbionts are tightly linked with the evolution of herbivory in ants. Proc. Nat. Acad. Sci. USA 2009, 106, 21236-21241. [CrossRef] [PubMed]

35. Ishak, H.D.; Plowes, R.; Sen, R.; Kellner, K.; Meyer, E.; Estrada, D.A.; Dowd, S.E.; Mueller, U.G. Bacterial diversity in Solenopsis invicta and Solenopsis geminata ant colonies characterized by $16 \mathrm{~S}$ amplicon 454 pyrosequencing. Microb. Ecol. 2011, 61, 821-831. [CrossRef] [PubMed]

36. Waite, D.W.; Dsouza, M.; Biswas, K.; Ward, D.F.; Deines, P.; Taylor, M.W. Microbial community structure in the gut of the New Zealand insect Auckland tree weta (Hemideina thoracica). Arch. Microbiol. 2015, 197, 603-612. [CrossRef] [PubMed]

37. Köhler, T.; Dietrich, C.; Scheffrahn, R.H.; Brune, A. High-resolution analysis of gut environment and bacterial microbiota reveals functional compartmentation of the gut in wood-feeding higher termites (Nasutitermes spp.). Appl. Environ. Microbiol. 2012, 78, 4691-4701. [CrossRef] [PubMed]

38. Gonzalez-Escobedo, R.; Briones-Roblero, C.I.; Pineda-Mendoza, R.M.; Rivera-Orduña, F.N.; Zúñiga, G. Bacteriome from Pinus arizonica and P. durangensis: Diversity, comparison of assemblages, and overlapping degree with the gut bacterial community of a bark beetle that kills pines. Front. Microbiol. 2018, 9, 77. [CrossRef] [PubMed]

39. Salinas-Moreno, Y.; Mendoza, G.; Barrios, M.A.; Cisneros, R.; Macías-Sámano, J.; Zúñiga, G. Areography of the genus Dendroctonus (Coleoptera: Curculionidae: Scolytinae) in Mexico. J. Biogeogr. 2004, 31, 1163-1177. [CrossRef]

40. Owen, D.R.; Smith, S.L.; Seybold, S.J. Red turpentine beetle. In Forest Insect and Disease Leaflet 55; US Department of Agriculture: Washington, DC, USA, 2010; p. 8.

41. Martiny, J.B.H.; Bohannan, B.J.M.; Brown, J.H.; Colwell, R.K.; Fuhrman, J.A.; Green, J.L.; Horner-Devine, M.C.; Kane, M.; Krumins, J.A.; Kuske, C.R.; et al. Microbial biogeography: Putting microorganisms on the map. Nat. Rev. Microbiol. 2006, 4, 102-112. [CrossRef] [PubMed]

42. Hanson, C.A. Microbial biogeography. In Encyclopedia of Biodiversity, 2nd ed.; Academic Press: San Diego, CA, USA, 2013; pp. 271-279.

43. Toju, H.; Fukatsu, T. Diversity and infection prevalence of endosymbionts in natural populations of the chestnut weevil: Relevance of local climate and host plants. Mol. Ecol. 2011, 20, 853-868. [CrossRef] [PubMed]

44. Zouache, K.; Raharimalala, F.N.; Raquin, V.; Tran-Van, V.; Raveloson, L.H.R.; Ravelonandro, P.; Mavingui, P. Bacterial diversity of field-caught mosquitoes, Aedes albopictus and Aedes aegypti, from different geographic regions of Madagascar. FEMS Microbiol. Ecol. 2011, 75, 377-389. [CrossRef] [PubMed]

45. Ceja-Navarro, J.A.; Vega, F.E.; Karaoz, U.; Hao, Z.; Jenkins, S.; Lim, H.C.; Kosina, P.; Infante, F.; Northen, T.R.; Brodie, E.L. Gut microbiota mediate caffeine detoxification in the primary insect pest of coffee. Nat. Commun. 2015, 6, 7618. [CrossRef] [PubMed]

46. Xu, L.; Lou, Q.; Cheng, C.; Lu, M.; Sun, J. Gut-associated bacteria of Dendroctonus valens and their involvement in verbenone production. Microb. Ecol. 2015, 70, 1012-1023. [CrossRef] [PubMed]

47. Redford, A.J.; Bowers, R.M.; Knight, R.; Linhart, Y.; Fierer, N. The ecology of the phyllosphere: Geographic and phylogenetic variability in the distribution of bacteria on tree leaves. Environ. Microbiol. 2010, 12, 2885-2893. [CrossRef] [PubMed]

48. Carrell, A.A.; Carper, D.L.; Frank, A.C. Subalpine conifers in different geographical locations host highly similar foliar bacterial endophyte communities. FEMS Microbiol. Ecol. 2016, 92, fiw124. [CrossRef] [PubMed]

49. Engel, P.; Moran, N.A. The gut microbiota of insects-Diversity in structure and function. FEMS Microbiol. Rev. 2013, 37, 699-735. [CrossRef] [PubMed]

50. Winder, R.S.; Macey, D.E.; Cortese, J. Dominant bacteria associated with broods of mountain pine beetle, Dendroctonus ponderosae (Coleoptera: Curculionidae, Scolytinae). J. Entomol. Soc. BC 2010, 107, 43-56.

51. Smith, R.H. Toxicity of pine resin vapors to three species of Dendroctonus bark beetles. J. Econ. Entomol. 1963, 56, 827-831. [CrossRef]

52. López, M.F.; Cano-Ramírez, C.; Shibayama, M.G.; Zúñiga, G. $\alpha$-pinene and myrcene induce ultrastructural change in the midgut of Dendroctonus valens (Coleoptera: Curculionidae: Scolytinae). Ann. Entomol. Soc. Am. 2011, 104, 553-561. [CrossRef] 
53. Chiu, C.C.; Keeling, C.I.; Bohlmann, J. Toxicity of pine monoterpenes to mountain pine beetle. Sci. Rep. 2017, 7, 8858. [CrossRef] [PubMed]

54. Navarro-Noya, Y.E.; Suárez-Arriaga, M.C.; Rojas-Valdes, A.; Montoya-Ciriaco, N.M.; Gómez-Acata, S.; Fernández-Luqueño, F.; Dendooven, L. Pyrosequencing analysis of the bacterial community in drinking water wells. Microb. Ecol. 2013, 66, 19-29. [CrossRef] [PubMed]

55. Caporaso, J.G.; Kuczynski, J.; Stombaugh, J.; Bittinger, K.; Bushman, F.D.; Costello, E.K.; Fierer, N.; Pena, A.G.; Goodrich, J.K.; Gordon, J.I.; et al. QIIME allows analysis of high-throughput community sequencing data. Nat. Methods 2010, 7, 335-336. [CrossRef] [PubMed]

56. Reeder, J.; Knight, R. Rapid denoising of pyrosequencing amplicon data: Exploiting the rank-abundance distribution. Nat. Methods 2010, 7, 668-669. [CrossRef] [PubMed]

57. Navas-Molina, J.A.; Peralta-Sánchez, J.M.; González, A.; McMurdie, P.J.; Vázquez-Baeza, Y.; Xu, Z.; Ursell, L.K.; Lauber, C.; Zhou, H.; Song, S.J.; et al. Advancing our understanding of the human microbiome using QIIME. Meth. Enzymol. 2013, 531, 371-444. [CrossRef] [PubMed]

58. Edgar, R.C. Search and clustering orders of magnitude faster than BLAST. Bioinformatics 2010, 26, $2460-2461$. [CrossRef] [PubMed]

59. Haas, B.J.; Gevers, D.; Earl, A.M.; Feldgarden, M.; Ward, D.V.; Giannoukos, G.; Ciulla, D.; Tabbaa, D.; Highlander, S.K.; Sodergren, E.; et al. Chimeric 16S rRNA sequence formation and detection in sanger and 454-pyrosequenced PCR amplicons. Genome Res. 2011, 21, 494-504. [CrossRef] [PubMed]

60. Caporaso, J.G.; Bittinger, K.; Bushman, F.D.; DeSantis, T.Z.; Andersen, G.L.; Knight, R. PyNAST: A flexible tool for aligning sequences to a template alignment. Bioinformatics 2010, 26, 266-267. [CrossRef] [PubMed]

61. Wang, Y.; Gilbreath, T.M.; Kukutla, P.; Yan, G.; Xu, J. Dynamic gut microbiome across life history of the malaria mosquito Anopheles gambiae in Kenya. PLoS ONE 2011, 6, e24767. [CrossRef] [PubMed]

62. Thompson, J.D.; Gibson, T.J.; Plewniak, F.; Jeanmougin, F.; Higgins, D.G. The CLUSTAL_X windows interface: Flexible strategies for multiple sequence alignment aided by quality analysis tools. Nucleic Acids Res. 1997, 25, 4876-4882. [CrossRef] [PubMed]

63. Darriba, D.; Taboada, G.L.; Doallo, R.; Posada, D. jModelTest 2: More models, new heuristics and parallel computing. Nat. Methods 2012, 9, 772. [CrossRef] [PubMed]

64. Letunic, I.; Bork, P. Interactive tree of life (iTOL) v3: An online tool for the display and annotation of phylogenetic and other trees. Nucleic Acids Res. 2016, 44, W242-W245. [CrossRef] [PubMed]

65. Chao, A.; Lee, S.M.; Chen, T.C.A. A generalized Good's nonparametric coverage estimator. Chin. J. Math. 1988, 16, 189-199.

66. Magurran, A.E. Ecological Diversity and Its Measurement; Princeton University Press: Princeton, NJ, USA, 1988.

67. Faith, D.P.; Baker, A.M. Phylogenetic diversity (PD) and biodiversity conservation: Some bioinformatics challenges. Evol. Bioinform. 2007, 2, 121-128. [CrossRef]

68. Zar, J.H. Biostatistical Analysis; Prentice-Hall: Upper Saddle River, NJ, USA, 2010.

69. Hammer, Ø.; Harper, D.A.T.; Ryan, P.D. PAST: Paleontological statistics software package for education and data analysis. Palaeontol. Electron. 2001, 4, 1-9.

70. Lozupone, C.; Lladser, M.E.; Knights, D.; Stombaugh, J.; Knight, R. UniFrac: An effective distance metric for microbial community comparison. ISME J. 2011, 5, 169-172. [CrossRef] [PubMed]

71. Bray, J.R.; Curtis, J.T. An Ordination of the upland forest community of southern Wisconsin. Ecol. Monogr. 1957, 27, 325-349. [CrossRef]

72. Rohlf, F.J. NTSYSpc Numerical Taxonomy and Multivariate Analysis System Version 2.0 User Guide; Applied Biostatistics Inc.: East Setauket, NY, USA, 1997.

73. Manly, B.F.J. Randomization, Bootstrap and Monte Carlo Methods in Biology 2; Chapman \& Hall: London, UK, 1997.

74. Langille, M.G.I.; Zaneveld, J.; Caporaso, J.G.; McDonald, D.; Knights, D.; Reyes, J.A.; Clemente, J.C.; Burkepile, D.E.; Thurber, R.L.V.; Knight, R.; et al. Predictive functional profiling of microbial communities using 16S rRNA marker gene sequences. Nat. Biotechnol. 2013, 31, 814-821. [CrossRef] [PubMed]

75. Kanehisa, M.; Goto, S.; Sato, Y.; Furumichi, M.; Tanabe, M. KEGG for integration and interpretation of large-scale molecular data sets. Nucleic Acids Res. 2011, 40, 109-114. [CrossRef] [PubMed]

(C) 2018 by the authors. Licensee MDPI, Basel, Switzerland. This article is an open access article distributed under the terms and conditions of the Creative Commons Attribution (CC BY) license (http://creativecommons.org/licenses/by/4.0/). 